\title{
NOVEL TECHNIQUE OF ACTIVE BIOMONITORING INTRODUCED IN THE CZECH REPUBLIC: BIOACCUMULATION OF ATMOSPHERIC TRACE METALS IN TWO MOSS SPECIES \\ NOVÁ METODA AKTIVNÍHO BIOMONITORINGU ZAVEDENÁ V ČESKÉ REPUBLICE: BIOAKUMULACE STOPOVÝCH KOVU゚ V ATMOSFÉŘE U DVOU DRUHŮ MECHŮ
}

\author{
Oldřich MOTYKA ${ }^{1}$, Barbora MACEČKOVÁ2, Jana SEIDLEROVÁ ${ }^{3}$, Blanka KREJČI ${ }^{4}$ \\ ${ }^{1}$ Mgr., Institute of Environmental Engineering, Faculty of Mining and Geology, \\ VŠB - Technical University of Ostrava, tr. 17.listopadu 15/2172, 70833 Ostrava-Poruba, \\ tel. $(+420) 596995264$ \\ e-mail: oldrich.motyka.st@vsb.cz \\ ${ }^{2}$ Bc., Institute of Environmental Engineering, Faculty of Mining and Geology, \\ $V \check{S} B$ - Technical University of Ostrava, tř. 17.listopadu 15/2172, 70833 Ostrava-Poruba, \\ tel. $(+420) 596995264$ \\ e-mail: barbora.maceckova.st@vsb.cz \\ ${ }^{3}$ Prof, Ing., CSc,. Department of Inorganic Analysis, Nanotechnology Center, \\ VŠB - Technical University of Ostrava, tř. 17.listopadu 15/2172, 70833 Ostrava-Poruba, \\ tel. (+420) 597321549 \\ e-mail: jana.seidlerova@vsb.cz \\ ${ }^{4}$ Mgr., Department of Air Quality Control, Czech Hydrometeorological Institute, \\ K myslivně 3/2182, 70800 Ostrava-Poruba \\ tel. (+420) 596900239 \\ e-mail: krejci@chmi.cz
}

\begin{abstract}
A biomonitoring technique never before used in the Czech Republic was used to test its validity and applicability in the region of Ostrava that is eminently affected by industry. Transplants of two moss species Hylocomium splendens and Pleurozium schreberi were exposed to atmospheric pollution using the technique of an "irrigated moss bag" placed at a height of both $1 \mathrm{~m}$ and $2 \mathrm{~m}$ above ground. The samples were then analysed for concentration levels of trace elements $\mathrm{Al}, \mathrm{As}, \mathrm{Cd}, \mathrm{Cr}, \mathrm{Cu}, \mathrm{Fe}, \mathrm{Hg}, \mathrm{Pb}, \mathrm{V}$ and $\mathrm{Zn}$. The patterns of bioaccumulation in general show that Hylocomium splendens is more suitable for monitoring purposes and that 2 $\mathrm{m}$ height above ground of transplants should be preferred.
\end{abstract}

Abstrakt

Za účelem validace byla pro biomonitoring v průmyslem ovlivněném regionu Ostravska použita metoda, která dosud v České republice nebyla aplikována. Transplantáty dvou druhů mechů Hylocomium splendens a Pleurozium schreberi byly vystaveny atmosférickému znečištění pomocí metody “irrigated moss bag” ve výšce jak $1 \mathrm{~m}$, tak $2 \mathrm{~m}$ nad zemí. Vzorky byly poté analyzovány za účelem zjištění koncentrace stopových prvkủ $\mathrm{Al}$, $\mathrm{As}, \mathrm{Cd}, \mathrm{Cr}, \mathrm{Cu}, \mathrm{Fe}, \mathrm{Hg}, \mathrm{Pb}, \mathrm{V}$ a Zn. Celkový průběh bioakumulace ukazuje, že je Hylocomium splendens pro biomonitoring vhodnější, stejně tak jako výška 2 m nad zemí.

Key words: biomonitoring, bryophytes, trace metals, atmospheric pollution, Hylocomium splendens, Pleurozium schreberi

\section{INTRODUCTION}

As our understanding of ecological demands of plants - both vascular and non-vascular - grows more and more, their usage as biomonitors of air quality is increasing rapidly. Among all generally known biomonitors, the 
importance of utilization of bryophytes with their bioindication properties enhances a lot. Common division in two categories of air quality biomonitors as presented in the review by Falla et al. (2001) mentions bryophytes in both of them:

1. Passive bioindicators: trees, lichens and mosses are used to determine the distribution and even the contaminants long-term effects on vast zones and, possibly, the concentrations of pollutants which they were exposed to.

2. Active bioindicators: tobacco and mosses make available the defective zones in plants and enable the determination of deposition fluxes.

The main difference between these two groups lies in the fact that, unlike passive bioindicators which are already present at the site under investigation, active bioindicators are imported to the site of interest from previous laboratory, greenhouse cultures (Garrec \& Radnai, 1996) or just simply from the site they are present at (e.g. Rosso et al., 2001).

As mentioned above, bryophyte species may be used both as active and passive bioindicators, which makes them a crucial bioindicative tool. There is a wide range of bryophytes employment in biomonitoring practice. Mosses are being used as monitors of climate changes (Gignac, 2001); because of their haploid set of chromosomes, they are much more vulnerable to mutagenic substances, which makes them useful for the indication of radioactive or other mutagenic pollution (Cove et al., 1997; Cove et al., 2006); transplants of bryophytes has been used for the long-term indication of ecological characteristics of forest environment, especially light conditions of the site (Rosso et al., 2001); water mosses, e.g. Fontinalis antipyretica, are able to indicate thermal pollution of any kind better than several technical appliances (Carballeira et al., 1998). Nevertheless, they play far most important role in the bioindication of air quality - especially their epiphytic species (both facultative and obligate). Epiphytic mosses are good air-quality monitors mainly due to the fact that their only water sources are atmospheric moisture and precipitations and their big desiccation tolerance allowing them to survive long time without water supply, still proceeding photosynthesis and thus ability to stay at the study site longer, still exposed to all possible pollutants (Proctor \& Tuba, 2002). Native terrestrial mosses are, according to the recent studies.

Mosses are being used for the indication of heavy metal deposition in the air; by spectroscopic analyses of their tissues we can say even absolute concentrations of their substances (e.g. Figueira et al., 2002). The data obtained this way are suitable for the long-term survey of heavy metal deposition at the site under investigation, for their gross intensity of accumulation is stable (Grodzińska \& Szarek-Łukaszevska, 2001; Chakrabortty \& Paratakar, 2006; Lucaciu et al, 2004,).

Beyond these advantages, bryophytes have several other characteristics that make them good bioindicators according to Tingey (1989):

- They are common in most of terrestrial ecosystems

- They are easy to work with due to their small size and low demands

- Their cultivation, storage and analyses are not expensive

Unlike in several other European countries, including its neighbours Germany or Poland, there was little or no attempt to utilize those features of bryophytes in biomonitoring of atmospheric pollution in the Czech Republic. The Czech Republic took part in the study concerning spatial differences in metal accumulation of bryophytes across boundaries (Schröder et al, 2007) and there was great effort put in the studies relating to the biomonitoring of trace metals in moss material with emphases on recent or past environmental loads (Suchara \& Sucharová; 2004, Suchara \& Sucharová, 2008), partially in the framework of the International Bryomonitoring Programme (Suchara \& Sucharová, 1998). However, those studies were rare and they used only passive biomonitoring techniques.

There was to this point no study dealing with active biomonitoring using mosses, this study therefore presents a novel approach in biomonitoring in the Czech Republic, it also presents one of the few utilizations of the irrigated moss bag method proceeded so far.

\section{MATERIAL AND METHODS}

\subsection{Moss material}

The material for transplants was obtained in the village of Staré Hamry, National Nature Reserve in the Moravskoslezské Beskydy Mts (NE Czech Rrepublic). The area for material collection was chosen due to its natural character and its distance from the source of industrial pollution. The collected samples of moss species 
Hylocomium splendens and Pleurozium schreberi are cosmopolitan and widely used in biomonitoring studies worldwide (e.g. Makholm \& Mladenoff, 2005; Pearson et al., 2000), therefore a comparison of outcomes is conceivable. Both species are abundant in the selected area, thus the moss collection poses no threat to their populations viability.

The moss material was carefully detached from its environment using sterilized latex gloves with a part of substrate - ensuring the moss layer not to be damaged - and moved to the laboratory. The apical segments of the thalli, approximately $4 \mathrm{~cm}$ long, were then excised, washed thoroughly in de-mineralized water and homogenized. Following the method by Al-Radady (Al-Radady et al., 1993) augmented by Fernández and Carballeira (Fernández \& Carballeira, 1999), the segments were then placed on capillary matting on the top of a polypropylene box. Sufficient moisture of the segments was assured by placing the ends of matting into the box full of distilled water ( 2 litres) through the slots on the sides of its top. To prevent the loss of the moss material due to the winds, the whole box was then wrapped in $1 \mathrm{~cm}$ aperture nylon net. The boxes prepared for exposition are presented in Fig. 1.

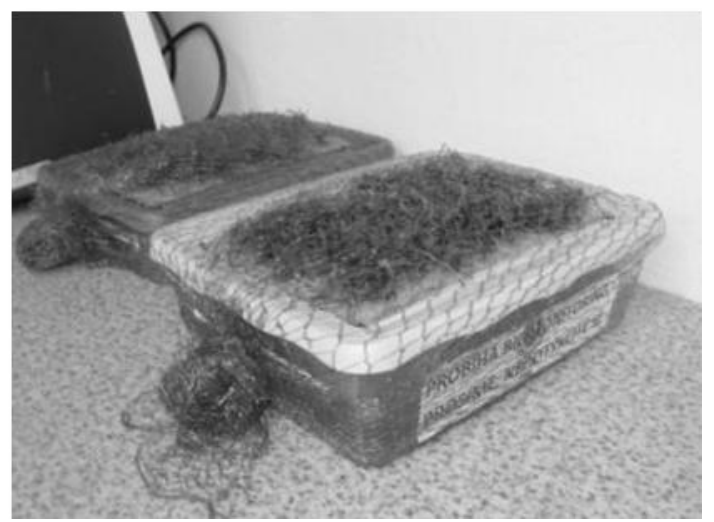

Fig. 1: Plastic box with moss material ready for exposition

\subsection{Transplants exposition}

The transplants of both species on the boxes were exposed in the area of the Czech Hydrometeorological Institute's "meteorological garden" in Ostrava-Poruba and placed on a metallic construction carrying standard monitoring equipment in heights of both $1 \mathrm{~m}$ and $2 \mathrm{~m}$. The exposed material was shaded and protected from rainfall by the shields of the construction.

The transplants were exposed twice for one month, first in October, then in November 2009. The transplants exposed in October were collected for analysis in two-week period, those exposed in November in the period of one week. There was only part of the material collected every time moved in a plastic bag into the laboratory and washed in de-mineralized water for $30 \mathrm{~s}$ in order to ablate the adhering matter that can cause bias in the analysis; longer washing can cause cell walls rupture and thus leakage of already accumulated elements (Fernández \& Carballeira, 1999). The samples were signed, enclosed in Petri dishes and dried out to the constant weight at $50^{\circ} \mathrm{C}$, for higher temperatures are known to cause loss of volatile elements (Fernández \& Carballeira, 1999). Subsequently, the samples were stored in desiccators to the time of analysis.

\subsection{Analysis}

The samples were analysed in the accredited laboratory of the Nanotechnology Centre of the VŠB-TUO. The concentrations of $\mathrm{Al}, \mathrm{As}, \mathrm{Cd}, \mathrm{Cr}, \mathrm{Cu}, \mathrm{Fe}, \mathrm{Hg}, \mathrm{Ni}, \mathrm{Pb}, \mathrm{V}$ and $\mathrm{Zn}$ were determined after the sample decomposition using atomic emission spectroscopy with inductively coupled plasma (AES - ICP), the instrument SPECTRO CIROS VISION. The instrument is an automatic optical emission spectrometer with the unique, patented, CIROS circular optical system and the remarkable UV-PLUS concept for high performance in the UV range, the entire relevant spectrum from 125 to $770 \mathrm{~nm}$ is captured simultaneously. The exited atoms and ions of sample emit element-specific radiation, and the intensity is measured using CCD detectors. The instrument is equipped with an axial plasma torch system. The measured elements intensities were evaluated by the Smart Analyzer software.

The obtained data was than analysed using the R statistical package (R Development Core Team, 2008) in attempt to find similar patterns of accumulation. The Pearson correlation coefficient was calculated. The accumulation rates of both mosses and both treatments, relative to the amount of particular metal, were put in bar graphs. 


\section{RESULTS AND DISCUSSION}

The accumulation rates of particular trace elements are presented in Fig. 2. It is apparent that the rates differ a lot considering the variables of species and height of the transplant. Though it was impossible to find a general regression model describing the accumulation of all elements at once, it is clear that, from both of used species, higher (and in general more positive) accumulation rates were those in the species Hylocomium splendens. Evaluating the treatment of exposed material of both species the accumulation can be generally considered higher when the transplants were exposed at a height of $2 \mathrm{~m}$ above ground, rather than those at a height of $1 \mathrm{~m}$. Although obvious exceptions are found, these results are most likely caused by some intrinsic factors that are hard to be taken into account.

An interesting observation is apparent, a sudden decrease of accumulation in more samples around the middle of the second exposition that can be considered even as a loss in the case of some elements (e.g. Cd, $\mathrm{Hg}$ ). According to the meteorological data collected simultaneously by CHMI (Czech Hydrometeorological Institute), this can be explained by the rapid decrease of temperature in the exposition period preceding the collection of the samples. The occurrence of ground frost could lead to the freezing of the moss material and thus cell walls rupture causing the leakage of already accumulated elements. The leaking of cytoplasmatic material due to the cell walls damage is well documented in bryophytes (Melick \& Seppelt, 1992), and though bryophytes are generally frost resistant when dried (Bewley \& Thorpe, 1974), they are much more vulnerable to the combination of high humidity and low temperatures (Dilks \& Proctor, 1975).

Tab. 1 Correlations between the accumulation patterns of particular elements in four different treatments. hs1, hs2 - Hylocomium splendens 1, 2 m height, ps1, ps2 - Pleurozium schreberi 1, 2 m height; *, **, *** - positive, $*, * *, * * *$ negative correlation $\alpha=0.1,0.05,0.01$

\begin{tabular}{|c|c|c|c|c|c|c|c|c|c|c|c|c|c|c|c|c|c|c|c|c|c|c|c|}
\hline hs2 & & & & & & & & & & & & hs1 & & & & & & & & & & & \\
\hline $\mathrm{Hg}$ & - & & & & & & & & & & & $\mathrm{Hg}$ & - & & & & & & & & & & \\
\hline As & $\mathrm{N}$ & - & & & & & & & & & & As & $\mathrm{N}$ & - & & & & & & & & & \\
\hline $\mathrm{Cd}$ & $\mathrm{N}$ & $\mathrm{N}$ & - & & & & & & & & & $\mathrm{Cd}$ & $\mathrm{N}$ & $\mathrm{N}$ & - & & & & & & & & \\
\hline $\mathrm{Pb}$ & $\mathrm{N}$ & $\mathrm{N}$ & $*$ & - & & & & & & & & $\mathrm{Pb}$ & $\mathrm{N}$ & $\mathrm{N}$ & $\mathrm{N}$ & - & & & & & & & \\
\hline$\overline{\mathrm{Ni}}$ & $\mathrm{N}$ & $\mathrm{N}$ & $\mathrm{N}$ & $\mathrm{N}$ & - & & & & & & & $\overline{\mathrm{Ni}}$ & $\mathrm{N}$ & $\mathrm{N}$ & $\mathrm{N}$ & $\mathrm{N}$ & - & & & & & & \\
\hline$\overline{\mathrm{Al}}$ & $\mathrm{N}$ & $\mathrm{N}$ & $\mathrm{N}$ & $\mathrm{N}$ & $*$ & - & & & & & & $\begin{array}{ll}\mathrm{Al} \\
\end{array}$ & $* *$ & $\mathrm{~N}$ & $\mathrm{~N}$ & $\mathrm{~N}$ & $\mathrm{~N}$ & - & & & & & \\
\hline $\mathrm{Cr}$ & $\mathrm{N}$ & $\mathrm{N}$ & $\mathrm{N}$ & $\mathrm{N}$ & $\mathrm{N}$ & $\mathrm{N}$ & - & & & & & $\mathrm{Cr}$ & $*$ & $* *$ & $\mathrm{~N}$ & $\mathrm{~N}$ & $\mathrm{~N}$ & $* * *$ & - & & & & \\
\hline $\mathrm{Cu}$ & $\mathrm{N}$ & $\mathrm{N}$ & $\mathrm{N}$ & $\mathrm{N}$ & $\mathrm{N}$ & $\mathrm{N}$ & $\mathrm{N}$ & - & & & & $\mathrm{Cu}$ & $\mathrm{N}$ & * & $\mathrm{N}$ & $\mathrm{N}$ & $\mathrm{N}$ & $\mathrm{N}$ & $\mathrm{N}$ & - & & & \\
\hline $\mathrm{Fe}$ & $\mathrm{N}$ & $\mathrm{N}$ & $\mathrm{N}$ & $\mathrm{N}$ & $\mathrm{N}$ & $\mathrm{N}$ & $\mathrm{N}$ & $\mathrm{N}$ & - & & & $\mathrm{Fe}$ & $* * *$ & * & $\mathrm{N}$ & $\mathrm{N}$ & $\mathrm{N}$ & $* * *$ & $* *$ & $\mathrm{~N}$ & - & & \\
\hline $\bar{V}$ & $\mathrm{~N}$ & $\mathrm{~N}$ & $\mathrm{~N}$ & $\mathrm{~N}$ & $\mathrm{~N}$ & $\mathrm{~N}$ & $\mathrm{~N}$ & $*$ & $* *$ & - & & $\bar{V}$ & $\mathrm{~N}$ & $\mathrm{~N}$ & $\mathrm{~N}$ & $\mathrm{~N}$ & $\mathrm{~N}$ & $\mathrm{~N}$ & $\mathrm{~N}$ & $\mathrm{~N}$ & $\mathrm{~N}$ & - & \\
\hline $\mathrm{Zn}$ & $\mathrm{N}$ & $\mathrm{N}$ & $\mathrm{N}$ & $* *$ & $\mathrm{~N}$ & $\mathrm{~N}$ & $\mathrm{~N}$ & $\mathrm{~N}$ & $\mathrm{~N}$ & $\mathrm{~N}$ & - & $\mathrm{Zn}$ & $\mathrm{N}$ & $*$ & $\mathrm{~N}$ & $\mathrm{~N}$ & $\mathrm{~N}$ & $\mathrm{~N}$ & $*$ & $\mathrm{~N}$ & $\mathrm{~N}$ & $\mathrm{~N}$ & - \\
\hline & $\mathrm{Hg}$ & As & $\mathrm{Cd}$ & $\mathbf{P b}$ & $\mathrm{Ni}$ & Al & $\mathrm{Cr}$ & $\mathbf{C u}$ & $\mathrm{Fe}$ & $\mathrm{V}$ & $\mathrm{Zn}$ & & $\mathrm{Hg}$ & As & Cd & $\mathbf{P b}$ & $\mathrm{Ni}$ & $\overline{\mathrm{Al}}$ & $\mathrm{Cr}$ & $\mathrm{Cu}$ & \begin{tabular}{|l|}
$\mathrm{Fe}$ \\
\end{tabular} & $\mathrm{V}$ & $\mathrm{Zn}$ \\
\hline ps2 & & & & & & & & & & & & \begin{tabular}{|l|} 
ps1 \\
\end{tabular} & & & & & & & & & & & \\
\hline $\mathrm{Hg}$ & & & & & & & & & & & & $\mathrm{Hg}$ & 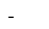 & & & & & & & & & & \\
\hline As & $\mathrm{N}$ & - & & & & & & & & & & As & $\mathrm{N}$ & - & & & & & & & & & \\
\hline$\overline{\mathrm{Cd}}$ & $\mathrm{N}$ & $\mathrm{N}$ & - & & & & & & & & & $\mathrm{Cd}$ & $\mathrm{N}$ & $*$ & - & & & & & & & & \\
\hline $\mathrm{Pb}$ & $\mathrm{N}$ & $\mathrm{N}$ & $* *$ & - & & & & & & & & $\mathrm{Pb}$ & $\mathrm{N}$ & $\mathrm{N}$ & $\mathrm{N}$ & - & & & & & & & \\
\hline$\overline{\mathrm{Ni}}$ & $\mathrm{N}$ & $\mathrm{N}$ & $\mathrm{N}$ & $* *$ & - & & & & & & & $\mathrm{Ni}$ & $\mathrm{N}$ & $\mathrm{N}$ & $\mathrm{N}$ & $\mathrm{N}$ & - & & & & & & \\
\hline$\overline{\mathrm{Al}}$ & $\mathrm{N}$ & $*$ & $\mathrm{~N}$ & $\mathrm{~N}$ & $\mathrm{~N}$ & - & & & & & & \begin{tabular}{|l|l}
$\mathrm{Al}$ \\
\end{tabular} & $\mathrm{N}$ & $\mathrm{N}$ & $\mathrm{N}$ & $\mathrm{N}$ & $\mathrm{N}$ & - & & & & & \\
\hline $\mathrm{Cr}$ & $\mathrm{N}$ & $\mathrm{N}$ & $\mathrm{N}$ & $\mathrm{N}$ & * & $\mathrm{N}$ & - & & & & & $\mathrm{Cr}$ & $\mathrm{N}$ & $\mathrm{N}$ & $\mathrm{N}$ & $* *$ & $\mathrm{~N}$ & $\mathrm{~N}$ & - & & & & \\
\hline $\mathrm{Cu}$ & $\mathrm{N}$ & $\mathrm{N}$ & $* *$ & $* * *$ & $* *$ & $\mathrm{~N}$ & $\mathrm{~N}$ & - & & & & $\mathrm{Cu}$ & $* *$ & $\mathrm{~N}$ & $\mathrm{~N}$ & $* *$ & $\mathrm{~N}$ & $\mathrm{~N}$ & $* *$ & - & & & \\
\hline$\overline{\mathrm{Fe}}$ & $\mathrm{N}$ & $*$ & $\mathrm{~N}$ & $\mathrm{~N}$ & $\mathrm{~N}$ & $* * *$ & $\mathrm{~N}$ & $\mathrm{~N}$ & - & & & $\mathrm{Fe}$ & $\mathrm{N}$ & $\mathrm{N}$ & $\mathrm{N}$ & $\mathrm{N}$ & $\mathrm{N}$ & $* * *$ & $\mathrm{~N}$ & $\mathrm{~N}$ & - & & \\
\hline $\bar{V}$ & $*$ & $*$ & $\mathrm{~N}$ & $\mathrm{~N}$ & $\mathrm{~N}$ & $* *$ & $\mathrm{~N}$ & $\mathrm{~N}$ & $* *$ & - & & $\mathrm{V}$ & $\mathrm{N}$ & $\mathrm{N}$ & $\mathrm{N}$ & $\mathrm{N}$ & $\mathrm{N}$ & $* *$ & $\mathrm{~N}$ & $\mathrm{~N}$ & $*$ & - & \\
\hline $\mathrm{Zn}$ & $\mathrm{N}$ & $\mathrm{N}$ & $\mathrm{N}$ & $\mathrm{N}$ & $\mathrm{N}$ & $\mathrm{N}$ & $* *$ & $\mathrm{~N}$ & $\mathrm{~N}$ & $\mathrm{~N}$ & - & $\mathrm{Zn}$ & $\mathrm{N}$ & $\mathrm{N}$ & $\mathrm{N}$ & $* *$ & $\mathrm{~N}$ & $\mathrm{~N}$ & $* *$ & $*$ & $\mathrm{~N}$ & $\mathrm{~N}$ & - \\
\hline & $\mathrm{Hg}$ & As & $\mathrm{Cd}$ & $\mathbf{P b}$ & $\mathrm{Ni}$ & Al & $\mathrm{Cr}$ & $\mathrm{Cu}$ & $\mathrm{Fe}$ & $\mathbf{V}$ & $\mathrm{Zn}$ & & $\mathrm{Hg}$ & As & Cd & $\mathbf{P b}$ & $\mathrm{Ni}$ & Al & $\mathrm{Cr}$ & $\mathrm{Cu}$ & \begin{tabular}{|l|}
$\mathrm{Fe}$ \\
\end{tabular} & $\mathbf{V}$ & $\mathrm{Zn}$ \\
\hline
\end{tabular}

The relations between particular elements accumulations in the moss tissue (Tab.1) were based on the Pearson correlation coefficient. Strikingly, there was a big difference observed among the treatments. Only positive correlations were found in the case of $P$. schreberi, but mostly negative correlations in $H$. splendens in a height of $1 \mathrm{~m}$ and almost none were found in Hylocomium splendens in a height of $2 \mathrm{~m}$ - including the strongest correlation of $\mathrm{Fe}$ and $\mathrm{Al}$ in other three treatments.

Correlations in elements amounts in thalli between the pairs of treatments were calculated as well, and those found are present in Table 3. In most of the elements, the correlation was weak or none. Therefore it can be concluded that the above ground height (as well as the species that is used) plays a big role in affecting accumulation rates in biomonitoring. In the correlations found, there is a clear distinction between the samples of $H$. splendens and $P$. Schreberi, but, in the case of $\mathrm{Cu}$ and $\mathrm{Zn}$, there was a satisfactory concurrence of metal amounts in both species samples placed $1 \mathrm{~m}$ above ground. 
Tab. 2 Correlations of accumulation patterns of $\mathrm{Hg}, \mathrm{Cr}, \mathrm{Cu}$ and $\mathrm{Zn}$ in pairs of treatments. hs1, hs2 Hylocomium splendens $1 \mathrm{~m}, 2 \mathrm{~m}$ heights; ps1, ps 2 - Pleurozium schreberi $1 \mathrm{~m}, 2 \mathrm{~m}$ heights.

\begin{tabular}{|l|l|l|l|l|}
\hline & hs1hs2 & ps1ps2 & hs1ps1 & hs2ps2 \\
\hline $\mathrm{Hg}$ & $* *$ & & & \\
\hline $\mathrm{Cr}$ & & $*$ & & \\
\hline $\mathrm{Cu}$ & & & $* *$ & \\
\hline $\mathrm{Zn}$ & & $* * *$ & $* *$ & $*$ \\
\hline
\end{tabular}


Fig. 2 Accumulation patterns of elements in both exposed moss species. H. s. - Hylocomium splendens, P. s. Pleurozium schreberi. 


\section{CONCLUSIONS}

This study presents a quite new method of biomonitoring in the Czech Republic and utilizes active biomonitoring using mosses, which is new in our conditions as well. The study is focused on the comparison of accumulation ability in two species of mosses Hylocomium splendens and Pleurozium schreberi and finding of appropriate height for atmospheric pollution measurement by those mosses.

Although the amount of several elements decreases, figures show that the appropriate height exposure is $2 \mathrm{~m}$ in the first period of exposition as well as in the consequent one. The height of $2 \mathrm{~m}$ is also preferable because it is the height in which the standard monitoring methods of atmospheric pollution is also provided; thus it is much more comparable with the data obtained by biomonitoring. When determining more suitable species for atmospheric pollution biomonitoring it is evident that, in the overall scale, Hylocomium splendens is much more exploitable.

Higher accumulation rates in Hylocomium splendens can be due to its sparse habitus which allows better air access, thus easier contact between pollutants and cells of the moss leaves. Another reason can be higher resilience and resistance to stress following the excision of apical segment. This can be incurred by different life cycles of this species - the only green (i.e. assimilating) part of the thallus is the latest innovation and the rest of the plant (older innovations) has mainly a sustaining and water storing function. Due to the elimination of hydric stress by continuous moisturizing through the capillary matting, $H$. splendens transplants were generally unharmed.

The accumulation rates of certain elements (e.g. Al, Cd, Zn) were found partly or wholly in minus levels (not depending on the treatment or species). Environmental factors such as air humidity, temperature and/or light exposure may influence the accumulation positively as well as they may cause cell walls ruptures in both high and low levels.

To the future application of the method, authors recommend to utilize rather Hylocomium splendens transplants placed in the height of $2 \mathrm{~m}$ and to enhance the extent of moss samples to assure accuracy in accumulation of other elements or compounds as well. The authors suggest this method either to supplement standard monitoring methods or independently. The study present means the first step for its further exploitation, improvement and accumulation comparison with the data obtained by standard monitoring.

\section{ACKNOWLEDGEMENTS}

Authors would like to thank Zbyněk Sovík for his counselling considering the determination and autecology of species used in the study.

\section{REFERENCES}

[1] AL-RADADY, A. S., DAVIES, B. E., FRENCH, M. J.: A new design of moss bag to monitor metal deposition both indoors and outdoors. Science of the Total Environment 1993, 113: 275 - 283.

[2] BEWLEY, J. D, THORPE, T. A.: On the metabolism of Tortula ruralis following desiccation and freezing: Respiration and carbohydrate oxidation. Plant Physiology. 1974, 32: 147-153.

[3] CARBALLEIRA, A., DÍAZ, S., VÁZQUEZ, M. D., LÓPEZ, J.: Inertia and resilience in the responses of the aquatic bryophyte Fontinalis antipyretica Hedw. to thermal stress. Archives of Environmental Contamination and Toxicology 1998, 34: 343-349

[4] COVE, D. J., KNIGHT, C. D., LAMPARTER, T.: Mosses as model systems. Trends in Plant Science 1997, 2: 99-105

[5] COVE, D. J., BEZANILlA, M., HARRIES, P.., QUATRANO, R.: Mosses as model systems for the study of metabolism and development. Annual Review of Plant Biology 2006, 57: 497-520

[6] DILKS, T. J. K., PROCTOR, M. C. F.: Comparative experiments on temperature responses of bryophytes: Assimilation, respiration and freezing damage. Journal of Bryology. 1975, 8: 317-336.

[7] FERNÁNDEZ, J., CARBALLEIRA, A.: Differences in the response of native and transplanted mosses to atmospheric pollution: a possible role of selenium. Environmental Pollution 1999, 110: 73-78.

[8] FIGUEIRA, R., SÉRGIO, C., SOUSA, A. J.: Distribution of trace metals in moss biomonitors and assessment of contamination sources in Portugal. Environmental Pollution 2002, 118: 153-163

[9] GARREC, J.-P., RADNAI, F.: Economical study and mapping of air pollution by plant bioindicators, Technical Report, INRA, Nancy, France, 1966, 12 p.

[10] GIGNAC, L. D.: Bryophytes as indicators of climate change. The Bryologist 2001, 104: 410-420 
[11] GRODZIŃSKA, K., SZAREK-ŁUKASZEWSKA, G.: Response of mosses to the heavy metal deposition in Poland - an overview. Environmental Pollution 2001, 114: 443-451.

[12] CHAKRABORTTY, S., PARATKAR, G. T.: Biomonitoring of trace element air pollution using mosses. Aerosol and Air Quality Research, Vol. 6, No.3, 2006, 6: 247-258.

[13] LUCACIU, A., TIMOFTE, L., CULICOV, O., FRONTASYEVA, M. V., OPREA, C., CUCU-MAN, S., MOCANU, R., STEINNES, E.: Atmospheric deposition of trace element in Romania studied by the moss biomonitoring technique. Journal of Atmospheric Chemistry 2004, 49: 533-548.

[14] MAKHOLM, M. M., MLADENOFF, D., J.: Efficacy of a biomonitoring (moss bag) technique for determining element deposition trends on a mid-range $(375 \mathrm{~km})$ scale. Environmental Monitoring and Assessment 2005, 104: 1-18.

[15] MELICK, D. R., SEPPELT, R. D.: Loss of soluble carbohydrates and changes in freezing point of Antarctic bryophytes after leaching and repeated freeze-thaw cycles. Antarctic science 1992, 4: 399-404

[16] PEARSON, J., WELlS, D. M., SELlER, K. J., BENNETT, A., SOARES, A., WOODALL, J., INGROUILEE, M. J.: Traffic exposure increases natural $15 \mathrm{~N}$ and heavy metal concentrations in mosses. New Phytologist 2000, 147: 317-326.

[17] PROCTOR, M. C. F., TUBA, Z.: Poikilohydry and homoihydry: antithesis or spectrum of possibilities? New Phytologist 2002, 156: 327-349

[18] R DEVELOPMENT CORE TEAM: R: A language and environment for statistical computing. R Foundation for Statistical Computing, 2008, Vienna, Austria. ISBN 3-900051-07-0, URL http://www.Rproject.org

[19] ROSSO. A. L., MUIR, R. S., RAMBO, T. R.: Using transplants to measure accumulation rates of epiphytic bryophytes in forests of western Oregon. The Bryologist 2001, 104: 30-439

[20] SCHRÖDER, W., HORNDMANN, I., PESCH, R., SCHMIDT, G., MARKERT, B., FRÄNZLE, S., WÜNSCHMANN, S., HEIDENREICH, H.: Nitrogen and metals in two regions in Central Europe: Significant differences in accumulation in mosses due to land use?. Environmental Monitoring and Assessment 2007, 133: 495-505

[21] SUCHAROVÁ, J., SUCHARA, I.: Atmospheric deposition levels of chosen elements in the Czech Republic determined in the framework of the International Bryomonitoring Program 1995. The Science of the Total Environment 1998, 223: 37-52

[22] SUCHARA, I., SUCHAROVÁ, J.: Distribution of 36 elements deposition rates in a historic mining and smelting area as determined through fine-scale biomonitoring techniques. Part II: Relative long-term accumulated atmospheric deposition levels. Water, Air, and Soil Pollution 2004, 153: 229-252.

[23] SUCHARA, I., SUCHAROVÁ, J.: Mercury distribution around the Spolana chlor-alkali plant (central Bohemia, Czech Republic) after a catastrophic flood, as revealed by bioindicators. Environmental Pollution 2008, 151: 352-361.

[24] TINGEY, D.T.: Bioindicators in air pollution research - Applications and constraints. In Biologic Markers of Air-Pollution Stress and Damage in Forests. Washington D.C., National Academies Press., 1989, pp. 73-80. ISBN: 978-0-309-07833-7.

\section{RESUMÉ}

Práce prezentuje výsledky zavedení dosud v České republice nepoužité metody aktivního biomonitoringu, takzvané ,,irrigated moss bag method“. Srovnáním dvou užitých druhů mechu, které jsou v biomonitoringu běžně užívány, ve dvou různých výškách nad zemí bylo zjištěno, že pro biomonitoring kvality ovzduší v Ostravě je vhodnější druh Hylocomium splendens oproti druhu Pleurozium schreberi. Na základě výsledků lze rovněž doporučit - u obou druhů - umístění transplantátů $2 \mathrm{~m}$ nad zemí.

Bioakumulace stopových prvků z atmosféry byla uspokojivá a zjištěné hodnoty se ukázaly být dosti citlivými pro monitoring v krátkém časovém intervalu i v př́ípadě velmi nízkých koncentrací. 